DOI: $10.17516 / 1997-1370-0548$

УДК 005.334.2

\title{
New in the Legislation \\ on Conciliation Procedures in Russia: Judicial Conciliation and Mediation
}

\author{
Anastasiya S. Arkhipkinaa,b, Igor V. Arkhipkin ${ }^{a}$ \\ and Marianna I. Dyachukc \\ ${ }^{a}$ East Siberian Branch of the Russian Academy of Justice \\ Irkutsk, Russian Federation \\ b"Baikal Mediators League” Association \\ Irkutsk, Russian Federation \\ 'Sarsen Amanzholov East Kazakhstan State University \\ Ust-Kamenogorsk, Republic of Kazakhstan
}

Received 19.01.2020, received in revised form 23.01.2020, accepted 12.02.2020

\begin{abstract}
The article is devoted to the analysis of the major changes in the Russian legislation on conciliation procedures that took place in 2019. The article focuses on a comparative analysis of the process and content of judicial conciliation and mediation, as well as the requirements for mediators in disputes settlement. Assessing the prospects for the development of the abovementioned conciliation procedures, the authors come to the conclusion about vivid advantages of judicial reconciliation, while noting that introduction of the concept of a "multi door courthouse", if successfully implemented, can contribute to the development of other alternative ways of disputes settlement.
\end{abstract}

Keywords: conciliation procedures, mediation, judicial reconciliation, protection of human rights, alternative dispute settlement procedure.

Research area: civil procedure; arbitration process.

(C) Siberian Federal University. All rights reserved

* Corresponding author E-mail address: nsakharova@yandex.ru ORCID: 0000-0003-4772-8974 (Arkhipkina) 


\section{Introduction}

Federal Law of July 26, 2019 No. 197-Ф3 "On Amendments to Certain Legislative Acts of the Russian Federation", adopted at the initiative of the Supreme Court of the Russian Federation, provides for amendments to Article 3 of the Law of the Russian Federation of June 26, 1992 No. 3132-I "On the Status of Judges in the Russian Federation", Fundamental Principles of the Legislation of the Russian Federation on the Notaries, Paragraph 4, Article 10 of the Federal Law of March 14, 2002 No. 30-Ф3 "On the Bodies of the Judicial Community in the Russian Federation", the Arbitration Procedure Code of the Russian Federation, Civil Procedure Code of the Russian Federation, in Part 1, Article 12 of the Federal Law of October 2, 2007, No. 229-Ф3 "On Enforcement Proceedings", Federal Law of July 27, 2010 No. 193-Ф3 “On Alternative Dispute Settlement Procedure with the Participation of a Mediator (Mediation Procedure)" and the Code of Administrative Judicial Procedure of the Russian Federation. The Law, which entered into force in October 2019 (with the exception of certain provisions), is aimed to improve conciliation procedures and help them become an effective tool for resolving disputes that contribute not only to improving the quality of justice by optimising judicial burden, but also, first of all, to reducing conflict intensity, strengthening social and business relations, establishment and development of partnership relations, formation of respectful attitude towards law, as well as increasing legal consciousness and social activity ${ }^{1}$.

The amendments proposed by the Law correspond to the tasks and principles of legal proceedings in courts of general jurisdiction and courts of arbitration, as well as to general trends in the development of procedural law as, among other things, defined in Resolution No. 1 of the IX All-Russian Congress of Judges of December 8, 2016 "On the Main Results of the Functioning of the Judicial System of the Russian Federation" and the priority areas of its development at the present stage.

\footnotetext{
1 On Amendments to Certain Legislative Acts of the Russian Federation: Federal Law of July 26, 2019 No. 197-Ф3
} (2019). In Rossiiskaia Gazeta, July, 31.
It is to be recalled that introduction of the mediation institute in 2010 was determined by the same goals and objectives. However, despite rather long period of validity of the Federal Law "On Alternative Dispute Settlement Procedure with the Participation of a Mediator (Mediation Procedure)", statistics on the relevance of judicial mediation remain implacable. The final certificate of the Supreme Court of the Russian Federation indicates the scanty number of disputes settled with the involvement of an intermediary after starting case proceedings in a court, which fits into the volume of statistical error (less than one and a half thousand cases out of more than 19 million cases considered in the first instance by courts of general jurisdiction and courts of arbitration) ${ }^{2}$.

Note that being legally enshrined since the entry into force of the Federal Law of July 27, 2010 No. 193-Ф3 “On Alternative Dispute Settlement Procedure with the Participation of a Mediator (Mediation Procedure)" mediation, as an instrument of protecting individual rights in Russia and an alternative way to resolve disputes, is still at the stage of its institutionalisation. Currently, there are a number of scientific works devoted to the study of implementing mediation and mediation technologies in the Russian legal system: Mediation in The Field of Civil Jurisdiction by S.I. Kalashnikova; Mediation in The System of Ways to Protect the Rights of Entrepreneurs by E.A. Dobrolyubova; Mediation in Criminal Proceedings by A.A. Arutyunyan; Mediation and Other Restorative Justice Programmes in the Criminal Justice System of the Anglo-Saxon Countries by A.S. Vasilenko; Mediation as an Alternative Method of International Commercial Disputes Resolution by V.I. Benova; Mediation as a Way of Protecting the Rights and Interests of Spouses in the Dissolution of Marriage by M.S. Ivanova; Mediation as an Alternative Form of Criminal Prosecution of Minors by E.E. Zabuga; Mediation as a Mechanism for

\footnotetext{
2 On Alternative Dispute Settlement Procedure with the Participation of a Mediator (Mediation Procedure): 2015 certificate on the practice of applying Federal Law of July 27, 2010 No. 193- $\Phi 3$ by the federal courts. Approved by the Presidium of the Supreme Court of the Russian Federation on 06.22.2016. Available at: http://www.vsrf.ru/Show_pdf. php?Id=8035 (accessed: 15.01.2020).
} 
Realising the Goal of Civil Proceedings by M.S. Nakhov; Mediation in the Socio-Legal Mechanism for Resolving Legal Conflicts by V.V. Kolomytseva; Mediation in the Culture of Regulating Interethnic Relations in Modern Russian Society by S.S. Shurenkova; Contemporary English-Language Discourse of Mediation: A Terminological Component and a System of Pragmatic Strategies by A.G. Monogarova; Mediation in Russia: Institutionalisation and Development of Mediation Practices by D.A. Chkhartishvili; Mediation in the Regulation of Interaction Between Authorities and Civil Society in Russia by S.A. Ryumshin, etc.

Analysing the aforementioned scientific works, it can be concluded that scientists study various aspects of applying mediation in the settlement of certain categories of disputes (family and labour disputes, disputes arising from entrepreneurial activities, etc.), as well as specific procedural aspects to apply mediation. It should be noted that the process of institutionalising mediation is also considered in terms of sociological approaches, and in some studies mediation is considered as the main non-governmental alternative institute and method for resolving social conflicts (e.g. S.M. Markov Mediation as Socio-Cultural Model of the Russian Legislation System Modernisation).

Introduction of a new method of resolving legal disputes into the Russian legal system has actualised the need to develop a system for introducing mediation into the activities of judicial bodies, state bodies and notaries. Existing studies (for instance, Ts.A. Shamlikashvili "Mediation as ADR Method. Focusing on Judges" and Ts.A. Shamlikashvili "Basics of Mediation as Dispute Resolution Method") were completed in 2010 - 2013, which indicates the necessity to update research data, taking into account existing practices and needs of an individual.

Mediation is an unconditional innovation of modern Russian legislation and it requires scientific understanding. Milokhova A.V. Development of Alternative Dispute Settlement Procedures: Mediation, Judicial Reconciliation, Judicial Mediation (2013), Mishchenko E.V. and Letuta T.V. "Principles of Judicial Conciliation, Mediation and Arbitration: Comparative Legal
Aspect", Afanasieva T.V. "Conciliation Procedures in the Concept of the Supreme Court of the Russian Federation", however, it should be noted that most of these works were published before the adoption of the amendments to the Russian legislation considered in this article.

Thus, it is necessary and relevant to conduct comparative legal analysis of the main conciliation procedures proposed by the legislator, and to assess their feasibility and efficiency, as well as real ability to fulfil the tasks assigned to them.

\section{Conciliation procedures: concept and types}

It should be noted that formulating general provisions of conciliation procedures as a procedural institution, securing the principles of conciliation procedures and specifying their main types, the legislator, nevertheless, does not define the concept of "conciliation procedures". Despite rather active use of this term, there is no established definition of it in legal science. The essence and content of conciliation procedures are often disclosed by the authors through the characteristics of the main types of conciliation procedures, without defining the concept (Semikina, Yusupova, 2016: 217-222). One of the most common definitions is the definition of conciliation procedure as a process of a set of actions to achieve a mutually acceptable and mutually beneficial result of settling a dispute or other legal uncertainty by parties in a legal relationship through direct negotiations between the parties, or with the involvement of a conciliator (intermediary, mediator) (Rozhkova, 2005: 148), (Solokhin, 2009: 15-16), (Solokhin, 2009: 26).

M.L. Skuratovsky gives the following definition: conciliation procedures are established by law procedural possibilities of the court of arbitration to facilitate the settlement of a dispute submitted to the court by taking measures under the control of the court to reach conciliation and terminate the proceedings. Skuratovsky highlights the following features: 1) the procedures are applied after the dispute is submitted to the court; 2) are carried out under the control of the court guided by the norms of procedural legislation, as well as eco- 
nomic and legal feasibility; 3) their goal is to dismiss the case by reconciliation of the parties (Arbitrazhnyi protsess: uchebnik, 2017: 188). It is believed that these signs reveal the content of conciliation procedures only in the context of their application in the arbitration process, and their value is significantly reduced. Since, for instance, mediation, identified by the legislator among conciliation procedures, can be applied before the dispute is submitted to the court. Speaking about the characteristic features of conciliation procedures, it is reasonable to highlight the purpose of their application and their essence, and the authors of the present paper fully agree with E.A. Treshcheva, who defines the purpose of conciliation procedures as bringing parties to an agreement (Treshcheva, 2012: 117). Of equal importance is the opinion of O.N. Zdrok who says that "the essence of the conciliation procedures is not the resolution of a dispute between the parties by someone else (even by a person chosen by mutual agreement of the parties) by making a binding decision for them, but development of an agreement. Moreover, a distinctive feature of conciliation procedures is the fact that during their application the parties themselves must find a mutually acceptable way to resolve the conflict" (Zdrok, 2012: 180-223). When characterising conciliation procedures, the authors do not pay enough attention to the study of such an essential feature as procedurality. The authors of the present paper consider the procedure as a certain sequence of actions aimed at achieving result. Thus, it is believed that the most essential signs of conciliation procedures are as follows: 1) the existence of a procedure, i.e., a certain sequence of actions aimed at achieving result; 2) the goal is to develop a mutually acceptable solution by the parties. These characteristics will be common to all types of conciliation procedures, and, it is certainly possible to add additional ones for each specific type. Based on the foregoing, the following definition can be formulated: conciliation procedure is the order of sequential actions necessary for the parties to develop a mutually acceptable agreement on the essence of a legal dispute.

Article 153.3 of the Code of Civil Procedure of the Russian Federation, Article 138.2 of the Arbitration Procedural Code of the Russian Federation and Article 137.3 of the Code of Administrative Judicial Procedure of the Russian Federation validate such types of conciliation procedures as negotiations, mediation, intermediation and judicial reconciliation. According to the Resolution of the Plenum of the Supreme Court of the Russian Federation of 01.18.2018 No. 1 "On Introducing into the State Duma of the Federal Assembly of the Russian Federation a Draft Federal Law "On Amendments to Certain Legislative Acts of the Russian Federation in Connection With Improvement of Conciliation Procedures" the terms "mediation" and "mediator" are used as generic terms, taking into account the fact that the terms "mediation", "mediator", "judicial reconciliation" and "judicial mediator" are specific in relation to them.

Indeed, despite the fact that intermediation is often considered to be equal to mediation (this was also facilitated by the title of the law "On an Alternative Dispute Resolution Procedure Involving a Mediator (Mediation Procedure)", it is considered necessary to understand it as a broader term that, along with mediation, includes other forms. In this way, in conflict resolution studies, mediation is understood as "a specific type of activity, which consists in optimising the process of search for a solution to the problem that would allow terminating the conflict by the conflicting parties with the participation of a third party" (Bol'shakov, Nesmelova, 2001: 40). Since the legislation on mediation in Russia essentially establishes facilitative mediation as the only type during the procedure, it can be assumed that other types of mediation can also be included into the term "intermediation" that is used by the procedural legislation.

In accordance with Article 153.4 of the Code of Civil Procedure of the Russian Federation and Article 138.3 of the Arbitration Procedural Code of the Russian Federation (introduced by the Federal Law of July 26, 2019 No. 197-Ф3), negotiations are the new legislatively established type of conciliation procedures.

There are different points of view on the concept of negotiation in the doctrine. I.N. Kuznetsov understands negotiations as "a 
means and relationship between people, intended to reach an agreement when the parties have coinciding or opposing interests" (Kuznetsov, 2014: 153-154).

M.G. Yatmanova defines negotiations as "conscious communication between people to achieve certain goals" (Yatmanova, 2012: 5).

The authors of the present paper consider the definition by Michael L. Spangle and Myra Warren Isenhart as the most acceptable one. According to their definition negotiations are a special type of communication in which parties: a) engage in reasoned discussions and problem-solving processes and b) develop shared understandings that serve as the basis for agreements (Spangle, Isenhart, 2009: 29). It is obvious that as a form of communication negotiations are one of the easiest ways to overcome disagreements, since they do not require additional resources and special knowledge for their implementation, and there is no strict legislative regulation regarding them, since in accordance with the legislation, negotiations are carried out according to the conditions developed by the parties. Within the meaning of the norm, the parties carry out negotiations independently or through their representatives, but without involving third parties (intermediary or mediator). Perhaps, in the future, these standards will be developed into the establishment of participatory procedures similar to the legislation of the Republic of Kazakhstan and other foreign countries. Adhering to the opinion that it is necessary to preserve dispositive principles in the regulation of negotiations, the authors of the present paper share the opinion of some authors on the feasibility of fixing the principle of good faith on the procedure for negotiating in any civil law situation, including in case of a dispute. In this way, the negotiating parties should consider each other's interests with a sufficient degree of good faith, reasonableness, care and prudence, which would exclude infliction of any harm to the other party (Erokhina, 2014: 168).

The legislator notes that in addition to the abovementioned types of conciliation procedures, the parties may use other ones, if this does not contradict the federal law.

\section{General characteristics of the main changes in the legislation on conciliation procedures}

The legislator provides the parties with the maximum opportunities for the dispute settlement and provides a flexible and diversified model of court assistance for reconciliation of the parties, which can take various forms. Based on the court proposal (which can be done either in the form of a decision or orally), with the consent of the parties or at the request of the parties, a conciliation procedure can be carried out at any stage of the process.

In accordance with the law, possible results of conciliation procedures include: amicable agreement settled on all or a part of the claims, partial or total rejection of the claim, its partial or full admission, full or partial rejection of the appeal, cassation appeal, supervisory appeal (submission), recognition of circumstances on which the other party bases its claims or objections, an agreement on the circumstances of the case and signing a letter of consent for state registration of a trademark. The conciliation agreement is indicated by the Code of Administrative Judicial Procedure as one of the possible results.

The new law proceeds from the fact that conciliation procedures, including mediation, can also be carried out in cases considered in administrative proceedings by the courts of general jurisdiction or arbitration courts. In this regard, the scope of the Federal Law "On an Alternative Dispute Resolution Procedure Involving a Mediator (Mediation Procedure)" has been expanded by including disputes arising from administrative and other public legal relations, including those connected with entrepreneurial and other economic activities. This innovation should be evaluated positively, since, as a technology, mediation has the potential to be applied for the settlement of various types of disputes, as evidenced by both the successful practice of foreign countries and the practice of Russian regions.

To reconcile the parties, clarify the factual circumstances and remove contradictions in their positions, the law empowered the court to postpone the trial or suspend the proceedings 
on its initiative and in the manner specified by the procedural legislation, offering the parties to use the conciliation procedure, including with the participation of a judicial conciliator.

Such actions may be performed by a court in the course of consideration of cases on contesting non-normative legal acts, decisions and actions (inaction) of bodies exercising public powers, other bodies, organisations granted specific state or other public powers, an official, state or municipal employee, as well as by recovery of mandatory payments and sanctions only in the case if the parties did not use pre-trial dispute settlement and with the consent of an organisation, sole trader or citizen.

At the same time, postponing the trial or suspending the proceedings on its initiative, the court does not force the parties to reconciliation, but only offers them to try to resolve the dispute themselves and to assess all the positive aspects of this method. In case of failure to reach an agreement on controversial issues, the trial continues.

The amendments to the law of the Russian Federation "On the Status of Judges in the Russian Federation" provided retired judges with the right to be mediators and judicial conciliators. This removed the existing discussion on the possibility of retired judges to be engaged in mediator activities on a professional basis. The register of mediators - retired judges will be kept by the councils of judges of the constituent entities of the Russian Federation.

The norm on the possibility of certifying the mediation agreement reached by the parties as a result of the mediation procedure carried out without submitting the dispute to the court by a notary and, thereby, giving it the force of an enforcement document, proposed by the legislator, caused an ambiguous reaction in the professional community of mediators. On the one hand, this significantly complicates the procedure, since after the development and achievement of a mediation agreement, an additional procedure for certifying the agreement by a notary is required. The mediation agreement, in this case, is certified with the participation of a mediator (mediators) who conducted this procedure in accordance with the agreement of the parties on the mediation procedure. Part 2, Ar- ticle 12 of the Federal Law "On an Alternative Dispute Resolution Procedure Involving a Mediator (Mediation Procedure)" establishes that the mediation agreement is subject to execution based on the principles of voluntariness and good faith of the parties. Voluntary execution of the mediation agreement is one of the essential characteristics of the mediation procedure and an indicator of the quality of its conduction. Russian and foreign mediators indicate a high feasibility of mediation agreements on a voluntary basis, which is confirmed, inter alia, by the aforementioned certificates of the Supreme Court of the Russian Federation on the practice of applying the Federal Law No. 193-Ф3 of July 27, 2010 by Russian courts. On the other hand, it was precisely the lack of executive power of the mediation agreement that was perceived as a drawback of mediation procedure by many lawyers ${ }^{3}$. Note, that information on several cases of notarisation of mediation agreements is in the open access. If this tendency continues, it will be possible to talk about the efficiency of the changes proposed by the legislator, as well as about the fact that this norm has indeed acted as an effective mechanism for the development of conciliation procedures. At the same time, there is a concern in the context of the provisions under consideration: since it is about pre-trial or out-of-court mediation, it can be carried out by non-professional mediators, i.e. any person who has reached the age of majority, has legal capacity and without criminal record may act as a mediator, which may lead to numerous abusive practices and depreciation of the mediation procedure. It appears that for the further institutionalisation of mediation and its formation as a special form of intermediation, it was necessary to provide for the possibility of notarisation only for the mediation agreements concluded as a result of conducting mediation procedure with the assistance of a professional mediator.

The abovestated and the analysis of the law give an opportunity to conclude that the main changes to the legislation in the field of medi-

\footnotetext{
The First Notarised Mediation Agreement Appeared in Russia. Available at: https://notariat.ru/ru-ru/news/v-rossii-poyavilos-pervoe-udostoverennoe-notariusom-mediativnoe-soglashenie (accessed 15.01.2020)
} 
ation concerned the expansion of the scope of its possible application by including disputes arising from administrative and other public legal relations; provided retired judges with an opportunity to carry out mediator's activities, as well as provided for the possibility of notarisation of a mediation agreement that validates the agreement as an executive document. Therewith, the legislator has not responded to requests from the professional community of mediators, in particular, the norm on the possibility of engaging non-professional mediators, the norm on the possibility of free mediator services, etc., have not been eliminated.

\section{Judicial conciliation and mediation: a comparative analysis}

The legislation provisions on the introduction of the institute of judicial conciliation, according to which the parties have the right to settle the dispute by using mediation procedure with the participation of a judicial mediator (judicial conciliation) are of particular interest.

To determine the prospects for the development of these conciliation procedures enshrined in the legislation, it seems appropriate to carry out comparative analysis, paying particular attention to the institutions of judicial conciliation and mediation, since, as for negotiations, the legislator limited himself to rather concise formulations that for the purpose of conciliation the parties have the right to resolve the dispute through negotiations carried out on the conditions determined by the parties.

Key terms. According to the procedural legislation and the Regulation, judicial conciliation is a conciliation procedure with the participation of a judicial mediator and is carried out by the parties in order to achieve a mutually acceptable result and resolve the conflict taking into account the interests of the parties. ${ }^{4}$

Mediation is a method of resolving disputes with the assistance of a mediator based on the voluntary consent of the parties in order to achieve a mutually acceptable solution. ${ }^{5}$

\footnotetext{
4 On approving the Regulation for Conducting Judicial Conciliation: Resolution of the Plenum of the Supreme Court of the Russian Federation of 10.31.2019. Available at: https:// rg.ru/2019/11/12/reglament-dok.html (accessed 19.12.2019)

5 On an Alternative Dispute Resolution Procedure Involving a Mediator (Mediation Procedure): the Federal Law of July 27 ,
}

Thus, it can be concluded that as forms of mediation, judicial conciliation and mediation have a common goal and are processes for the settlement of disputes involving a third party.

Mediator is an independent individual involved by the parties to act as an intermediary in the settlement of a dispute. The law specifies the following requirements for mediators (since we consider the issue of conciliation proceedings after the dispute is submitted to the court, we are talking about the requirements for professional mediators): age over 25 years, higher education, legal capacity, lack of criminal record, additional professional training in mediation. It should be noted that there are currently no uniform requirements for the training of mediators. The authors of the present paper believe that the programmes offered by educational centres should form the necessary skills and competencies of mediators as provided for in the professional standard. ${ }^{6}$ The latest changes to Article 16 of the Federal Law "On an Alternative Dispute Resolution Procedure Involving a Mediator (Mediation Procedure)" is supplemented by a provision on the possibility of conducting mediator's activity by retired judges. A literal interpretation of this provision gives an opportunity to conclude that there are no additional requirements for acquiring additional competencies, which is not reasonable, since the professional conduct of the mediation procedure involves not only and not so much excellent knowledge of substantive and procedural law, but also knowledge in the field of psychology, conflict resolution, negotiations and sociology.

In case of judicial conciliation, the judicial mediator - retired judges act as the third party, and their list is compiled and approved by the Plenum of the Supreme Court of the Russian Federation. The experience of working as a judge, scientific activity, areas of practice, the region of the candidate's residence, the activities carried out by the retired judge from the moment of resignation, as well as compliance

2010 No.193-Ф3 (2010). In Rossiiskaia Gazeta, July, 30.

6 On the Approval of the Professional Standard "Specialist in the Field of Mediation (Mediator)": order of the Ministry of Labour and Social Protection of the Russian Federation of December 15, 2014, No. 1041 H. Available at: https://base.garant. $\mathrm{ru} / 70843342 /$ (accessed: 17.12.2019) 
of this activity with the legislation on the status of judges and the Code of Judicial Ethics are taken into account when including in the list.

The principles of conciliation procedures. The principles of the conciliation procedures under consideration are willingness, cooperation, equality of parties, independence and impartiality of the person conducting the conciliation procedure (a mediator or judicial mediator) and confidentiality. The regulation of judicial conciliation gives details of the basic principles, while as for the principles of the mediation procedure, the legislator gave only their statement.

Willingness as a principle of conciliation procedure means, above all, voluntary participation of all parties. As for the mediation procedure, the scientific literature notes that willingness is absolute, that is, parties voluntarily come to the mediation procedure, voluntarily remain in it, voluntarily participate in the development of a mediation agreement and voluntarily execute it. In the process of judicial conciliation, parties also voluntarily determine the procedure for its conduct and results and may also refuse to participate in the conciliation procedure at any stage.

Cooperation. The Regulation of Judicial Conciliation indicates that parties cooperate with each other, with the judicial mediator and with the court. The negotiations of parties are constructive and productive in nature, aimed at resolving the dispute, and are held in an atmosphere of trust and mutual respect. The same can be attributed to the mediation procedure where parties have to cooperate both with the mediator and with each other. At the same time, the authors of the present paper adhere to the opinion that the proclamation of cooperation is not enough, the mediator needs to create conditions under which parties do not compete, but are looking for ways to satisfy their interests by developing a mutually acceptable solution, perceiving another party, above all, as a partner to solve the problem.

Equality of parties. Both in the process of mediation procedure and judicial conciliation procedure, parties enjoy equal rights to determine the candidacy of mediators, negotiators, the rules and procedure for the media- tion, individual work with the mediator, access to the information discussed, development and formulation of proposals for the dispute settlement, assessment of their acceptability and feasibility, as well as exercise their rights and legitimate interests.

The judicial conciliator or mediator is not entitled to put any of the parties in a preferential position by his/her actions, as well as to diminish rights of one of the parties.

Independence and impartiality of the person conducting the conciliation procedure. In judicial conciliation, an important characteristic of this principle is independence of the activity of the judge - mediator and his/her independence from the judge who handles the case. It is indicated that the attitude of the judicial mediator towards each of the parties is impartial, respectful and considerate, and it is necessary to ensure equal participation of the parties in judicial conciliation. The judicial mediator must inform the court and the parties of any circumstances that may raise doubts about its independence and impartiality. The judicial mediator is independent and carries out his/her activities independently, without the participation of the judge who handles the case. In the course of the mediation procedure, the mediator must act as an independent person, while the legislator establishes that the mediator is not entitled to carry out mediator activities if, during the procedure, the mediator personally (directly or indirectly) is interested in its result and, among other things, is a relative of one of the parties. Based on the requirements of the legislator to the mediator, he/she should be free from other professional obligations to the parties, in particular, he/she cannot act as their representative or consultant, which guarantees independence and impartiality.

Confidentiality. This principle is indicated in the literature as one of the advantages of alternative dispute resolution procedures. The legislation establishes confidentiality of all information related to the specified procedure, with the exception of cases provided for by federal laws, and unless the parties have agreed otherwise. So, the mediator is not entitled to disclose information related to the mediation procedure and which became known to him/ 
her during the procedure, without the consent of the parties. Parties and organisations involved in ensuring the mediation procedure, as well as other persons who were present during the mediation procedure, regardless of whether the judicial proceedings or arbitration is related to the dispute that was the subject of the mediation procedure, is not entitled to refer, unless the parties agreed otherwise, in the course of judicial proceedings or arbitration, to the information:

1) on the proposal of one of the parties to apply the mediation procedure, as well as the readiness of one of the parties to participate in this procedure;

2) on the opinions or proposals expressed by one of the parties regarding the possibility of resolving the dispute;

3 ) on confessions made by one of the parties during the mediation process;

4) the readiness of one of the parties to accept the proposal of the mediator or another party to resolve the dispute.

Requesting information on the mediation procedure from the mediator and from the organisation carrying out mediation activities is not allowed, except for the cases provided for by federal laws and unless the parties agree otherwise.

Within the framework of judicial conciliation, all information created or obtained during judicial conciliation is confidential and is not subject to disclosure or dissemination by the participants of judicial conciliation without the written consent of the parties. Parties have the right to determine restrictions on dissemination of information related to judicial conciliation.

The Regulation of judicial conciliation also notes such principle of procedure as good faith. In contrast to other principles of judicial conciliation, the content of this principle is not disclosed in a separate article of the Regulation, however, the analysis of the provisions of Articles 13 and 14 gives an opportunity to conclude that this principle means good faith in conducting judicial conciliation for a judicial mediator and good faith in the use of rights by the parties. The authors of the present paper believe that this principle of judi- cial conciliation should be studied separately, however, it can be assumed that the term good faith is used with different semantic content. In this way, in relation to the judicial mediator, the term good faith is used in its literal meaning - honest performance of one's duties (Ozhegov, 2009: 148). And in relation to the parties, as a category that is widely used to characterise participants of civil law relations (Deryugina, 2010: 46-49).

Stages of conciliation procedures. In accordance with the Regulation, judicial conciliation may include the following stages:

starting judicial conciliation (opening statement of a judicial mediator);

statement of circumstances of the dispute and determination of the parties' interests; formulation of issues for discussion by the parties;

individual conversation of the judicial mediator with the parties and their representatives; development of proposals for the dispute settlement and achievement of conciliation results by the parties;

documentation of the conciliation results, including conclusion of a settlement agreement, a reconciliation agreement, an agreement on actual fact, preparation of non-suit or acceptance of a claim;

completion of judicial conciliation.

Unless the parties and the judicial mediator agree otherwise, the procedure and the need for any stages of judicial mediation are determined by the judicial mediator, taking into account the nature, complexity and circumstances of the dispute, as well as wishes of the parties.

The judicial mediator manages the negotiation process, forms and supports its constructive and productive nature, provides each party with an opportunity to express their opinion on the causes of the dispute, its essence and goals that the parties intend to achieve through judicial conciliation, ensures compliance with the norms of the negotiation process, reduces the level emotional judgments of the parties, prevents the parties from using rude and offensive language, and calls for action pursued by law, ensures correct and respectful relations between the parties, to a 
court conciliator and other parties, takes other steps to create a favourable atmosphere for the negotiations.

In the process of judicial conciliation the judicial mediator establishes actual relations between the parties, ascertains the content of reciprocal claims, opinions of the parties regarding the possibilities of resolving the dispute, helps to identify the interests of the parties, and assists the parties in finding mutually beneficial results of conciliation.

In this way, it is possible to conclude that the classical mediation procedure which involves a similar process of negotiating and consideration of interests, but not positions of the parties is practically integrated into the new judicial conciliation procedure, (Arkhipkina, Filatova, 2017: 21-34), (Besemer, 2004: 68-110). Moreover, unlike a mediator, who cannot consult the parties and propose solutions (unless the parties stipulate otherwise), the judge-mediator can give the parties recommendations to resolve the dispute as soon as possible, to maintain business relations between the parties (in particular, to propose the plaintiff to verify the legitimacy, propriety and reasonableness of the recovery amount; to invite the defendant to check the validity of the claim objections; to offer the parties to conduct additional payments reconciliation, to discuss the terms of the contract from which the dispute arose, comparing the circumstances of their fulfilment or non-fulfilment by the parties with the nature of claims, find out the unambiguous understanding of the terms of the contract by the parties, and other legal relations); in addition, the judge-mediator must explain the law and practice of its application to the parties; and to offer the parties to elaborate and discuss variants for dispute settlement (optimal, satisfactory, and undesirable). The result of judicial reconciliation may be an amicable agreement, an agreement on reconciliation, or an agreement on actual fact, which are prepared by the parties with the help of a judicial mediator.

It appears that all this, combined with the free-of-charge basis of the judicial reconciliation procedure for the parties, makes this procedure more attractive compared to other conciliation procedures.

\section{Conclusion}

The analysis of the current Russian legislation on conciliation procedures allows to draw the following conclusions:

1. There is no legal definition of the concept of conciliation procedures. In this connection, the authors of the present paper offer the following definition: conciliation procedure is the order of sequential actions necessary for the parties to develop a mutually acceptable agreement on the essence of a legal dispute. The most significant features of conciliation procedures include: 1) procedural nature - the existence of a procedure, i.e., a specific sequence of actions aimed at achieving a result; 2) the goal - development of a mutually acceptable solution by the parties;

2. The main types of conciliation procedures include negotiations, intermediation, including judicial conciliation and mediation.

3. Judicial conciliation and mediation are forms of intermediation, which represents disputes settlement involving the third party. These procedures have similar basis (principles) and structure. Moreover, under current conditions the procedure of judicial conciliation has several advantages: it is conducted by a highly qualified person, whose qualification and authority are recognised in the field of law; due to the detailed elaboration in the Regulation of judicial conciliation, it has a structure that is clear to the participants; the decision reached as a result is binding; judicial conciliation is free-of-charge for the parties.

4. While positively assessing endowing the mediation agreement with executive power, the authors of the present paper consider it necessary to introduce into the legislation norms on the possibility of notarising only mediation agreements reached as a result of the mediation process with the assistance of a professional mediator.

5. Introduction of the institute of judicial conciliation solves the issue of reducing the load on the judicial system only indirectly, since the judicial mediators' activities are, nevertheless, provided by the system itself: information resources, premises for conducting conciliation procedures and payroll funds. However, in case 
of its successful implementation, the concept of the "multi-door courthouse" can contribute to the development of alternative ways of resolving disputes.

\section{References}

Arbitrazhnyi protsess: uchebnik [The Arbitration Process: Textbook] (2017). Ed. by V.V. Yarkov. $7^{\text {th }}$ Edition. Moscow, Statut, $188 \mathrm{p}$.

Arkhipkina, A.S., Filatova, U.B. (2017). Mediatsiia kak effektivnyi sposob uregulirovaniia sporov: problemy razvitiia i mekhanizmy vnedreniia [Mediation as an Effective Way to Resolve Disputes: Problems of Development and Implementation Mechanisms]. Irkutsk, ISU Publishing House, 109 p.

Besemer, C. (2004). Mediatsiia. Posrednichestvo v konfliktakh [Mediation - Vermittlung in Konflikten]. Translation form German by N.V. Malovoi. Kaluga, Dukhovnoe poznanie, $176 \mathrm{p}$.

Bol'shakov, A.G., Nesmelova, M.Yu. (2001). Konfliktologiia organizatsiii [Organisations Conflictology]. Moscow, MZ Press, $181 \mathrm{p}$.

Deryugina, T.V. (2010). Sushchnost' poniatiia dobrosovestnosti v grazhdanskom prave Rossii [The Legal Nature of the Concept of Good Faith in the Civil Law of Russia]. In Iurist-Pravoved [Lawyer-Legal Scholar]. Rostov-on-Don, Publishing House of Rostov Law Institute of the Ministry of Internal Affairs of Russia, 3, 46-49.

Erokhina, E.V. (2014). Peregovory kak odin iz sposobov al'ternativnogo razresheniia grazhdansko-pravovogo spora [Negotiations as a Way of Alternative Resolution of Civil Legal Disputes]. In Vestnik VolGU: Seriia 5: Iurisprudentsiia [Science Journal of Volgograd State University. Jurisprudence], 4 (25), 168.

Zdrok, O.N. (2012). Primiritel'nye protsedury v grazhdanskom sudoproizvodstve: poniatie, klassifikatsiia, tendentsii razvitiia (na primere Respubliki Belarus') [Conciliation Procedures in Civil Proceedings: The Concept, Classification, Development Trends (Case Study: the Republic of Belarus), In Vestnik grazhdanskogo protsessa [Herald of Civil Procedure], 1, 180-223.

Kuznetsov, I.N. (2014). Delovoe obshchenie: Uchebnoe posobie dlia bakalavrov [Business Communication: A Textbook for Bachelors]. Rostov-on-Don, Feniks, 335 p.

Ozhegov, S.I. [2009]. Tolkovyi slovar' russkogo iazyka [Dictionary of the Russian Language]. Moscow, Oniks, 736 p.

Rozhkova, M.A. (2005). Mirovaia sdelka: ispol'zovanie v kommercheskom oborote [Amicable Agreement: Commercial Use]. Moscow, Statut, 148 p.

Semikina, S.A., Yusupova, A.N. (2016). Primiritel'nye protsedury v kontekste sravnitel'nogo analiza protsessual'nogo zakonodatel'stva Rossii i drugikh gosudarstv [The Conciliation Procedures in the Context of Comparative Analysis of the Procedural Legislation of Russia and Other Countries]. In Vestnik Saratovskoi gosudarstvennoi iuridicheskoi akademii [Saratov State Law Academy Bulletin], 3(110), 217-222.

Solokhin, A. (2009). Nekotorye problemy poniatiia "primireniia" v nauke arbitrazhnogo protsessa i praktike arbitrazhnykh sudov [Certain Problems of the Concept of "Conciliation" in the Science of Arbitrazh Procedure and Practice of Arbitrazh Courts]. In Arbitrazhnyi i grazhdanskii protsess [Arbitrazh and Civil Procedure], 7, 15-16.

Solokhin, A. (2009). Mirovoe soglashenie kak rezul'tat primireniia zaiavitelia i gosudarstva-otvetchika v Evropeiskom Sude po pravam cheloveka [Amicable Agreement as a Result of Conciliation of Applicant and the State Defendant in the European Court for Human Rights]. In Arbitrazhnyi i grazhdanskii protsess [Arbitrazh and Civil Procedure], 1, 26.

Spangle, M.L., Isenhart, M.W. (2009). Peregovory. Reshenie problem v raznom kontekste [Negotiation: Communication for Diverse Settings]. Translated from English, HIU, Publishing House Humanitarian Centre, $592 \mathrm{p}$.

Treshcheva, E.A. (2012). Pravovoe regulirovanie primiritel'nykh protsedur na sovremennom etape [Legal Regulation of Conciliation Procedure at the Present Stage]. In Vestnik Samarskogo gosudarstvennogo universiteta [Vestnik of Samara University], 3/2 (94), 88-92. 
Treshcheva, E.A. (2012). Sudebnye primiritel'nye protsedury: pravo na sushchestvovanie [Judicial Settlement Procedures: A Right to Exist]. In Razvitie mediatsii v Rossii: teoriia, praktika, obrazovanie: sbornik statei [Development of Mediation in Russia: Theory, Practice, Education], Ed. by E.I. Nosyreva, D.G. Fil'chenko. Moscow-Berlin, Infotropic Media, 117.

Yatmanova, M.G. (2012). Vedenie peregovorov. Strategii i taktiki: uchebno-metodicheskoe posobie [Negotiation. Strategies and Tactics: Study Guide]. Saint Petersburg, Saint Petersburg State University, $92 \mathrm{p}$.

\title{
Новое в законодательстве \\ о примирительных процедурах в России: судебное примирение и медиация
}

\author{
А.С.Архипкинаа,б, И.В.Архипкин ${ }^{\mathrm{a}}$ М.И.Дячукв \\ ${ }^{a}$ Восточно-Сибирский филиал Российского государственного \\ университета правосудия \\ Российская Федераиия, Иркутск \\ ${ }^{\sigma}$ Ассоииачия «Байкальская лига медиаторов» \\ Российская Федераџия, Иркутск \\ ${ }^{8}$ Восточно-Казахстанский государственный университет \\ имени Сарсена Аманжолова \\ Республика Казахстан, Усть-Каменогорск
}

\begin{abstract}
Аннотация. Статья посвящена анализу основных изменений российского законодательства о примирительных процедурах, произошедших в 2019 году. Основное внимание уделяется сравнительному анализу процесса и содержания судебного примирения и медиации, а также требований, предъявляемых к посредникам в урегулировании споров. Оценивая перспективы развития названных примирительных процедур, авторы приходят к выводу о явных преимуществах судебного примирения, отмечая при этом, что внедрение концепции «суда со множеством дверей» в случае ее успешного воплощения может способствовать развитию и других альтернативных способов решения споров.
\end{abstract}

Ключевые слова: примирительные процедуры, медиация, судебное примирение, защита прав человека, альтернативная процедура урегулирования споров.

Научная специальность: 12.00.15 - гражданский процесс; арбитражный процесс. 